\title{
Inositol 1,4,5-trisphosphorothioate, a stable analogue of inositol trisphosphate which mobilizes intracellular calcium
}

\author{
Colin W. TAYLOR, ${ }^{*} \ddagger$ Michael J. BERRIDGE,* Allan M. COOKE $\dagger$ and Barry V. L. POTTER $\nmid \S$ \\ *A.F.R.C. Unit of Insect Neurophysiology and Pharmacology, Department of Zoology, Downing Street, Cambridge CB2 3EJ, \\ U.K., and †Department of Chemistry, Leicester University, Leicester LE1 7RH, U.K.
}

\begin{abstract}
D-Ins $(1,4,5) P_{3}$ is now recognized as an intracellular messenger that mediates the actions of many cell-surface receptors on intracellular $\mathrm{Ca}^{2+}$ pools, but its complex and rapid metabolism in intact cells has confused interpretation of its possible roles in oscillatory changes in intracellular $\left[\mathrm{Ca}^{2+}\right]$ and in controlling $\mathrm{Ca}^{2+}$ entry at the plasma membrane. We now report the actions and metabolic stability of a synthetic analogue of Ins $(1,4,5) P_{3}$, DL-inositol 1,4,5-trisphosphorothioate [DL-Ins $\left.(1,4,5) P_{3}[\mathrm{~S}]_{3}\right]$. In permeabilized hepatocytes, DL-Ins $(1,4,5) P_{3}[\mathrm{~S}]_{3}$ and synthetic DL-Ins $(1,4,5) P_{3}$ stimulated $\mathrm{Ca}^{2+}$ release from the same intracellular stores, though the concentration required for half-maximal release was 3 -fold higher for DL-Ins $(1,4,5) P_{3}[\mathrm{~S}]_{3}$. Since L-Ins $(1,4,5) P_{3}$ neither antagonized the effects of D-Ins $(1,4,5) P_{3}$ nor itself stimulated appreciable $\mathrm{Ca}^{2+}$ release, the activity of the racemic mixture of $\operatorname{Ins}(1,4,5) P_{3}$, and presumably also of $\operatorname{Ins}(1,4,5) P_{3}[\mathrm{~S}]_{3}$, is attributable to the $\mathrm{D}$-isomer. Under conditions where there was negligible metabolism of $\mathrm{D}$ - $\left[{ }^{3} \mathrm{H}\right] \operatorname{Ins}(1,4,5) P_{3}$, both DL-Ins $(1,4,5) P_{3}$ and DL-Ins $(1,4,5) P_{3}[\mathrm{~S}]_{3}$ elicited rapid $\mathrm{Ca}^{2+}$ release from intracellular stores, and the stores remained empty during prolonged stimulation. When cells were incubated at high density, both compounds stimulated rapid $\mathrm{Ca}^{2+}$ release, but while the stores soon refilled as $\operatorname{Ins}(1,4,5) P_{3}$ was degraded to $\operatorname{Ins}(1,4) P_{2}$, there was no refilling of the pools after stimulation with DL-Ins $(1,4,5) P_{3}[\mathrm{~S}]_{3}$. When DL-Ins $(1,4,5) P_{3}$ or DL-Ins $(1,4,5) P_{3}[\mathrm{~S}]_{3}$ was treated with a crude preparation of $\operatorname{Ins}(1,4,5) P_{3} 3$-kinase and ATP, and the $\mathrm{Ca}^{2+}$ releasing activity of the products subsequently assayed, DL-Ins $(1,4,5) P_{3}$ was completely inactivated by phosphorylation, but there was no loss of activity of the phosphorothioate analogue. In additional experiments, DL-Ins $(1,4,5) P_{3}[\mathrm{~S}]_{3}(10 \mu \mathrm{M})$ did not affect the rate of phosphorylation of $\mathrm{D}-\left[{ }^{3} \mathrm{H}\right] \operatorname{Ins}(1,4,5) P_{3}$ $(1 \mu \mathrm{M})$. We conclude that $\operatorname{Ins}(1,4,5) P_{3}[\mathrm{~S}]_{3}$ is a full agonist and only 3 -fold less potent than $\operatorname{Ins}(1,4,5) P_{3}$ in mobilizing intracellular $\mathrm{Ca}^{2+}$ stores, but unlike the natural messenger it is resistant to both phosphorylation and dephosphorylation. We propose that this stable analogue will allow the direct actions of $\operatorname{Ins}(1,4,5) P_{3}$ to be resolved from those that require its metabolism.
\end{abstract}

\section{INTRODUCTION}

Activation of many cell-surface receptors evokes both hydrolysis of PtdIns $(4,5) P_{2}$ (Berridge \& Irvine, 1984; Downes \& Michell, 1985) and an increase in cytosolic $\mathrm{Ca}^{2+}$ concentration. The latter response is frequently a series of transient oscillations (Woods et al., 1986; Berridge et al., 1988) that are often independent of extracellular $\mathrm{Ca}^{2+}$ and in some cells are mimicked by intracellular application of D-Ins $(1,4,5) P_{3}$ (Parker \& Miledi, 1986). D-Ins $(1,4,5) P_{3}$ is unusual among intracellular messengers in the complexity of its metabolism (Majerus et al., 1988); it may either be dephosphorylated to D-Ins $(1,4) P_{2}$ (Storey et al., 1984) and probably thereby inactivated, or phosphorylated to D-Ins $(1,3,4,5) P_{4}$ (Irvine et al., 1986), a product that may regulate $\mathrm{Ca}^{2+}$ transport at the plasma membrane (Irvine \& Moor, 1986; Morris et al., 1987).

Phosphorothioate compounds have found wide use in mechanistic enzymology and molecular biology as analogues of naturally-occurring substrates (Eckstein, 1985). DL-myo-Inositol 1,4,5-trisphosphorothioate (DL-Ins $\left.(1,4,5) P_{3}[\mathrm{~S}]_{3}\right)$, in which each phosphate group of Ins $(1,4,5) P_{3}$ has been replaced by a phosphorothioate group, was recently synthesized (Cooke et al., 1987a,b) as a potential phosphatase-resistant analogue of $\operatorname{Ins}(1,4,5)$ $P_{3}$. We have earlier shown that $\operatorname{Ins}(1,4,5) P_{3}[\mathrm{~S}]_{3}$ mobilizes $\mathrm{Ca}^{2+}$ from the intracellular stores of both Xenopus oocytes and permeabilized Swiss 3T3 cells (Taylor et al., 1988), and more recent studies have confirmed our observations (Strupish et al., 1988). We now report that in permeabilized hepatocytes, DL-Ins $(1,4,5) P_{3}[\mathrm{~S}]_{3}$ mobilizes intracellular $\mathrm{Ca}^{2+}$ stores, that it is a full agonist, only 3fold less potent than DL-Ins $(1,4,5) P_{3}$, and furthermore its actions are prolonged because it is resistant to both phosphorylation and dephosphorylation. We expect this stable analogue of Ins $(1,4,5) P_{3}$ to find widespread use in analyses of inositol phosphate actions and metabolism, both as a long-lived analogue of the natural messenger and as a compound that cannot be further metabolized to other active messengers.

\section{MATERIALS AND METHODS}

Measurement of ${ }^{45} \mathrm{Ca}$ release from intracellular pools of permeabilized hepatocytes

Hepatocytes were prepared by collagenase digestion of livers removed from male Wistar rats (about $200 \mathrm{~g}$ ) (Taylor \& Putney, 1985). The cells were kept in cold

Abbreviations used: Ins $(1,4,5) P_{3}[\mathrm{~S}]_{3}$, inositol 1,4,5-trisphosphorothioate. Isomeric configurations are defined in the text.

$\ddagger$ Author for correspondence.

$\S$ Author for correspondence relating to supply of $\operatorname{Ins}(1,4,5) P_{3}[\mathrm{~S}]_{3}$.

Vol. 259 
Eagle's medium supplemented with $2 \%(\mathrm{w} / \mathrm{v})$ bovine serum albumin until required. Cells were permeabilized by incubation with saponin $(75 \mu \mathrm{g} / \mathrm{ml})$ for $10 \mathrm{~min}$ at $37^{\circ} \mathrm{C}$ in a $\mathrm{Ca}^{2+}$-free cytosol-type medium $(140 \mathrm{~mm}-\mathrm{KCl} / 20 \mathrm{~mm}$ $\mathrm{NaCl} / 2 \mathrm{~mm}-\mathrm{MgCl}_{2} / 1$ mm-EGTA/20 mm-Pipes, pH 6.8/ $2 \%$ bovine serum albumin. After permeabilization, the cells were washed and resuspended at low cell density $(0.2-0.4 \mathrm{mg}$ of protein $/ \mathrm{ml})$ in the same medium with $\mathrm{Ca}^{2+}$ added to give a free $\left[\mathrm{Ca}^{2+}\right]$ of about $120 \mathrm{~nm}$ (Berridge et al., 1984). Permeabilized cells were added to ${ }^{45} \mathrm{CaCl}_{2}$ $(2 \mu \mathrm{Ci} / \mathrm{ml})$, oligomycin $(10 \mu \mathrm{M})$ and antimycin $(10 \mu \mathrm{M})$, and 1 min later ${ }^{45} \mathrm{Ca}^{2+}$ uptake into non-mitochondrial pools was initiated by addition of ATP $(1.5 \mathrm{mM})$, creatine phosphate $(5 \mathrm{~mm})$ and creatine phosphokinase (1 unit/ $\mathrm{ml})$. At $20 \mathrm{~min}$, Ins $(1,4,5) P_{3}$ or $\operatorname{Ins}(1,4,5) P_{3}[\mathrm{~S}]_{3}$ was added, and $5 \mathrm{~min}$ later samples of cells $(200 \mu 1)$ were diluted into $2 \mathrm{ml}$ of cold iso-osmotic sucrose ( $310 \mathrm{mM}$ ) containing EGTA $(4 \mathrm{~mm})$ and either $\left[{ }^{3} \mathrm{H}\right]$ mannose or ${ }^{3} \mathrm{H}_{2} \mathrm{O}(0.3 \mu \mathrm{Ci} / \mathrm{ml})$ to correct for trapped volume. The samples were rapidly filtered through Whatman GF/C filters (Burgess et al., 1983) and the filters were washed with $5 \mathrm{ml}$ of sucrose/EGTA. After correction for trapped volume, the ${ }^{45} \mathrm{Ca}^{2+}$ contents of cells were calculated and the release stimulated by $\operatorname{Ins} P_{3}$ was expressed as a fraction of ATP-dependent ${ }^{45} \mathrm{Ca}^{2+}$ uptake.

Treatment of inositol phosphates with $\operatorname{Ins}(1,4,5) P_{3}$ 3-kinase

A rat-brain homogenate $\left(4^{\circ}{ }_{0}\right.$ in $500 \mathrm{~mm}$-Tris/ maleate/150 mm-sucrose, $\mathrm{pH} 7.5$ ) was centrifuged at $1400 \mathrm{~g}$ for $10 \mathrm{~min}$ at $4{ }^{\circ} \mathrm{C}$ (Irvine et al., 1986; Tennes et al., 1987), and the supernatant fraction was stored frozen until required. DL-Ins $(1,4,5) P_{3}$ or DL-Ins $(1,4,5)$ $P_{3}[\mathrm{~S}]_{3}(100 \mu \mathrm{M})$ were added to the supernatant $(2 \%)$ in sucrose $(150 \mathrm{~mm})$ containing $\mathrm{MgSO}_{4}(20 \mathrm{~mm})$ and buffered with Tris/maleate $(500 \mathrm{~mm}$; $\mathrm{pH} 7.5)$. After $1 \mathrm{~min}$, ATP $(10 \mathrm{~mm})$, creatine phosphate $(10 \mathrm{~mm})$ and creatine phosphokinase ( 5 units $/ \mathrm{ml}$ ) were added, and the incubation was continued for a further $60 \mathrm{~min}$ at $37^{\circ} \mathrm{C}$. Samples $(20 \mu \mathrm{l})$ were transferred to tubes and the incubations were terminated by heating at $70^{\circ} \mathrm{C}$ for $3 \mathrm{~min}$. Earlier experiments established that this procedure for stopping incubations caused no loss of activity of either $\operatorname{Ins}(1,4,5) P_{3}$ or $\operatorname{Ins}(1,4,5) P_{3}[\mathrm{~S}]_{3}$. The activities of the inositol phosphate samples were subsequently determined by addition of $200 \mu \mathrm{l}$ of permeabilized hepatocytes prelabelled to steady state with ${ }^{45} \mathrm{Ca}^{2+}$ as described above. Results, corrected for the small ${ }^{45} \mathrm{Ca}^{2+}$ release stimulated by incubation medium alone, are shown as a percentage of ATP-dependent ${ }^{45} \mathrm{Ca}$ uptake.

\section{Separation of inositol phosphates}

The metabolism of inositol phosphates was determined by including $\left[{ }^{3} \mathrm{H}\right] \mathrm{D}-\mathrm{Ins}(1,4,5) P_{3}$ (final activity in most experiments, $0.2 \mu \mathrm{Ci} / \mathrm{ml}$ ) with the incubations. Reactions were terminated by addition of $400 \mu \mathrm{l}$ of cold $4.5 \%$ (w/v) $\mathrm{HClO}_{4}$ to $200 \mu \mathrm{l}$ of cells, followed by addition of $50 \mu$ l of phytic acid hydrolysate (about $1 \mathrm{mg}$ of $P / \mathrm{ml}$ ) (Wreggett \& Irvine, 1987). After centrifugation, the supernatant was neutralized (Sharpes \& McCarl, 1982), EDTA ( $5 \mathrm{~mm}$ ) was added, and the sample was stored frozen before analysis by either h.p.l.c. or anion-exchange chromatography.

For h.p.l.c. analysis, samples were loaded on to a Partisil 10 SAX anion-exchange h.p.l.c. column, and $\left[{ }^{3} \mathrm{H}\right.$ ]inositol phosphates were eluted with linear $\mathrm{NH}_{4} \mathrm{CO}_{2} \mathrm{H}$ gradients as follows $\left(\mathrm{pH} 3.7\right.$ with $\left.\mathrm{H}_{3} \mathrm{PO}_{4}\right)$ : 0-5 min, water; $5-27.5 \mathrm{~min}$, water $-0.84 \mathrm{~m} ; 27.5-40 \mathrm{~min}$, $0.84-3.4 \mathrm{M}$; flow rate $1.2 \mathrm{ml} / \mathrm{min}$. Fractions (30 s) were counted in Hi-salt Scint (Zinsser Analytic) scintillation cocktail. Peaks were identified by comparison with absorbance $(259 \mathrm{~nm})$ from added adenine nucleotides and by their co-elution with authentic standards.

In some experiments, $\left[{ }^{3} \mathrm{H}\right]$ inositol phosphates were separated on $3 \mathrm{~cm}$ columns of AG1-X8 (formate form) anion-exchange resin in Pasteur pipettes. Samples $(2 \mathrm{ml})$ were loaded on to the columns and $\left[{ }^{3} \mathrm{H}\right]$ inositol phosphates were eluted: inositol, $8 \mathrm{ml}$ of distilled water; Ins $P_{1}, 8 \mathrm{ml}$ of $0.2 \mathrm{M}-\mathrm{NH}_{4} \mathrm{CO}_{2} \mathrm{H}$ in $0.1 \mathrm{M}-\mathrm{HCO}_{2} \mathrm{H}$; Ins $P_{2}$, $8 \mathrm{ml}$ of $0.5 \mathrm{M}-\mathrm{NH}_{4} \mathrm{CO}_{2} \mathrm{H}$ in $0.1 \mathrm{M}-\mathrm{HCO}_{2} \mathrm{H}$; Ins $P_{3}, 8 \mathrm{ml}$ of $0.95 \mathrm{M}-\mathrm{NH}_{4} \mathrm{CO}_{2} \mathrm{H}$ in $0.1 \mathrm{M}-\mathrm{HCO}_{2} \mathrm{H}$; Ins $P_{4}, 8 \mathrm{ml}$ of $1.25 \mathrm{M}-\mathrm{NH}_{4} \mathrm{CO}_{2} \mathrm{H}$ in $0.1 \mathrm{M}-\mathrm{HCO}_{2} \mathrm{H}$. With this procedure, inositol, Ins $P_{1}$, Ins $P_{2}$ and Ins $P_{3}$ were completely resolved, and $\operatorname{Ins} P_{3}$ and $\operatorname{Ins} P_{4}$ were separated with only about $1.3^{\circ}$ of the Ins $P_{4}$ fraction collected in the Ins $P_{3}$ fraction and only $3.4 \%$ of Ins $P_{3}$ collected in the Ins $P_{4}$ fraction. Since the method does not separate isomers of inositol phosphates, it was used only when h.p.l.c. analyses indicated that such separations were unnecessary (see the Results section).

\section{Effects of Ins $\left.(1,4,5) P_{3} \mid \mathrm{S}\right]_{3}$ on phosphorylation of Ins $(1,4,5) P_{3}$}

[ $\left.{ }^{3} \mathrm{H}\right] \mathrm{D}-\mathrm{Ins}(1,4,5) P_{3}(0.1 \mu \mathrm{Ci} / \mathrm{ml}$; final concentration of D-Ins $\left.(1,4,5) P_{3}, 10 \mu \mathrm{M}\right)$ was incubated with the brain supernatant preparation under identical conditions to those used to determine its effects on the activity of inositol phosphates (see above). Samples of $200 \mu \mathrm{l}$ were removed at various times and stopped with $400 \mu \mathrm{l}$ of cold $\mathrm{HClO}_{4}(4.5 \%)$, and the samples were then neutralized and the products separated as described above. Recovery of the added radiolabel was $90 \pm 6 \%$ $(n=6)$ after the $60 \mathrm{~min}$ incubation.

\section{Materials}

D-Ins $(1,4,5) P_{3}, \quad\left[{ }^{3} \mathrm{H}\right] \mathrm{D}-\operatorname{Ins}(1,4,5) P_{3} \quad(1 \mathrm{Ci} / \mathrm{mmol})$ and D-Ins $\left(1,4,\left[{ }^{32} \mathrm{P}\right] 5\right) P_{3}$ (about $\left.1000 \mathrm{Ci} / \mathrm{mmol}\right)$ were from Amersham. Collagenase, ATP, creatine phosphate and creatine phosphokinase were from Boehringer Mannheim. DL-Ins $(1,4,5) P_{3}$, L-Ins $(1,4,5) P_{3}$ and DLIns $(1,4,5) P_{3}[\mathrm{~S}]_{3}$ were synthesized as described (Cooke et al., 1987a,b). All other reagents were from the suppliers given in earlier publications.

\section{RESULTS}

\section{Effects of Ins $P_{3}[\mathrm{~S}]_{3}$ on intracellular $\mathrm{Ca}^{2+}$ pools}

Permeabilized hepatocytes sequestered ${ }^{45} \mathrm{Ca}^{2+}$ into a non-mitochondrial pool when provided with ATP. Within $10 \mathrm{~min}$ a steady state was reached, and by $20 \mathrm{~min}$ the ${ }^{45} \mathrm{Ca}^{2+}$ content of the cells had risen from $0.36 \pm 0.06$ to $3.88 \pm 0.57 \mathrm{nmol} / \mathrm{mg}$ of protein (mean \pm S.E.M. ; $n=14)$. Addition of a maximally effective concentration of D-Ins $(1,4,5) P_{3}(100 \mu \mathrm{M})$ stimulated release of $60 \%$ of that $\mathrm{Ca}^{2+}$ pool, and half-maximal release occurred with $0.4 \mu \mathrm{M}$ (Fig. 1a). Since the phosphorothioate analogue of Ins $(1,4,5) P_{3}$ was prepared as a racemic mixture of the two enantiomers, we examined the effect of the synthetic enantiomer of $\mathrm{D}-\operatorname{Ins}(1,4,5) P_{3}$. L-Ins $(1,4,5) P_{3}$ failed to stimulate $\mathrm{Ca}^{2+}$ release at concentrations of up to $10 \mu \mathrm{M}$ and even at $100 \mu \mathrm{M}$ it stimulated release of only $15 \%$ of 


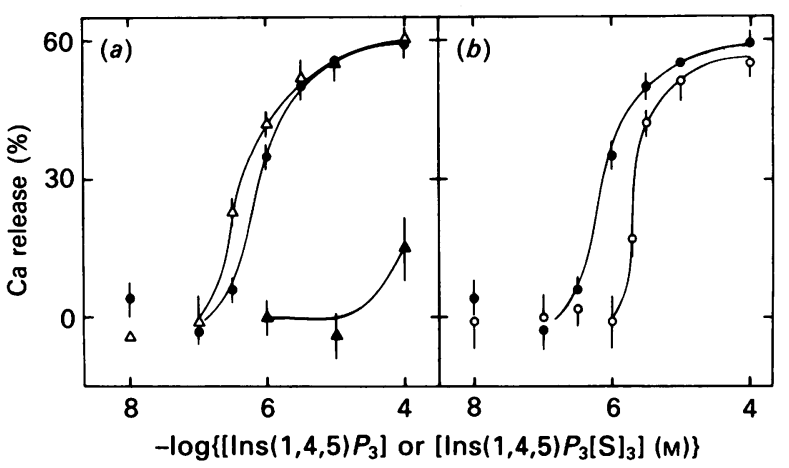

Fig. 1. Concentration-effect relationships for $\operatorname{Ins}(1,4,5) P_{3}$ - and Ins $(1,4,5) P_{3}[S]_{3}$-induced $\mathrm{Ca}^{2+}$ release from permeabilized hepatocytes

Permeabilized cells at low cell density were labelled to steady state with ${ }^{45} \mathrm{Ca}$ in the presence of mitochondrial inhibitors and then incubated with various inositol phosphates for $5 \mathrm{~min}$. The release of ${ }^{45} \mathrm{Ca}^{2+}$ evoked by the inositol phosphates, as a percentage of ATP-dependent uptake, is shown as the mean \pm S.E.M. of duplicate determinations from between four and nine independent experiments. $\Delta, \mathrm{L}-\operatorname{Ins}(1,4,5) P_{3} ; \triangle, \mathrm{D}-\operatorname{Ins}(1,4,5) P_{3} ; O$, DL$\operatorname{Ins}(1,4,5) P_{3} ; \bigcirc$, DL-Ins $(1,4,5) P_{3}[\mathrm{~S}]_{3}$.

the ATP-dependent $\mathrm{Ca}^{2+}$ pool (Fig. 1a). The responses to near-maximal $(10 \mu \mathrm{M})$ or submaximal $(0.3 \mu \mathrm{M})$ concentrations of D-Ins $(1,4,5) P_{3}$ were unaffected by the simultaneous presence of L-Ins $(1,4,5) P_{3}(10 \mu \mathrm{M})$ (results not shown). As expected from these results, a maximally effective concentration of the wholly synthetic racemic mixture of Ins $(1,4,5) P_{3}$ released the same amount of $\mathrm{Ca}^{2+}$ as did D-Ins $(1,4,5) P_{3}$, though the concentration-response relationship was shifted such that half-maximal release occurred at an approx. 2-fold higher concentration $(0.75 \mu \mathrm{M})$ (Fig. 1a).

Fig. 1(b) compares the effects of DL-Ins $(1,4,5) P_{3}$ and DL-Ins $(1,4,5) P_{3}[\mathrm{~S}]_{3}$ on intracellular $\mathrm{Ca}^{2+}$ pools. The responses to maximal concentrations of each were similar, i.e. release of about $60 \%$ of accumulated $\mathrm{Ca}^{2+}$, and a combined application of maximal concentrations of each evoked no greater release. Half-maximal responses occurred at $0.75 \mu \mathrm{M}$ for DL-Ins $(1,4,5) P_{3}$ and $2.1 \mu \mathrm{M}$ for DL-Ins $(1,4,5) P_{3}[\mathrm{~S}]_{3}$. The results presented in Fig. 1(a) demonstrate that the biological activity of DL-Ins $(1,4,5) P_{3}$ is entirely attributable to the D-isomer. By analogy, it seems likely that only the D-isomer of DL-Ins $(1,4,5) P_{3}[\mathrm{~S}]_{3}$ is capable of stimulating $\mathrm{Ca}^{2+}$ release.

Under the conditions used to determine these concentration-effect relationships (the cells were washed after permeabilization and then resuspended at low cell density), there was negligible metabolism of $\left[{ }^{3} \mathrm{H}\right]_{\mathrm{D}}$ $\operatorname{Ins}(1,4,5) P_{3}$ (Fig. $\left.2 b\right)$. The relative activities of $\operatorname{Ins}(1,4,5) P_{3}$

at high cell density with DL-Ins $(1,4,5) P_{3} \quad(10 \mu \mathrm{M}) \quad(c)$ degraded $\left[{ }^{3} \mathrm{H}\right] \mathrm{D}-\operatorname{Ins}(1,4,5) P_{3}$ with a half-time of about $10 \mathrm{~min}$. Most of that degradation occurred by the 5phosphatase pathway [at $30 \mathrm{~min}, 83 \%$ of activity was recovered as Ins $\left.+\operatorname{Ins} P+\operatorname{Ins}(1,4) P_{2}\right]$ with only a very minor contribution from the 3-kinase pathway $[8 \%$ of activity recovered as $\left.\operatorname{Ins}(1,3,4) P_{3}+\operatorname{Ins}(1,3,4,5) P_{4}\right]$. These results demonstrate that under the conditions used to examine the time course of the actions of DL-Ins $(1,4,5) P_{3}$ at high cell density (Fig. 3a), degradation of $\mathrm{D}$ - $\operatorname{Ins}(1,4,5) P_{3}$ is dominated by 5-phosphatase action.
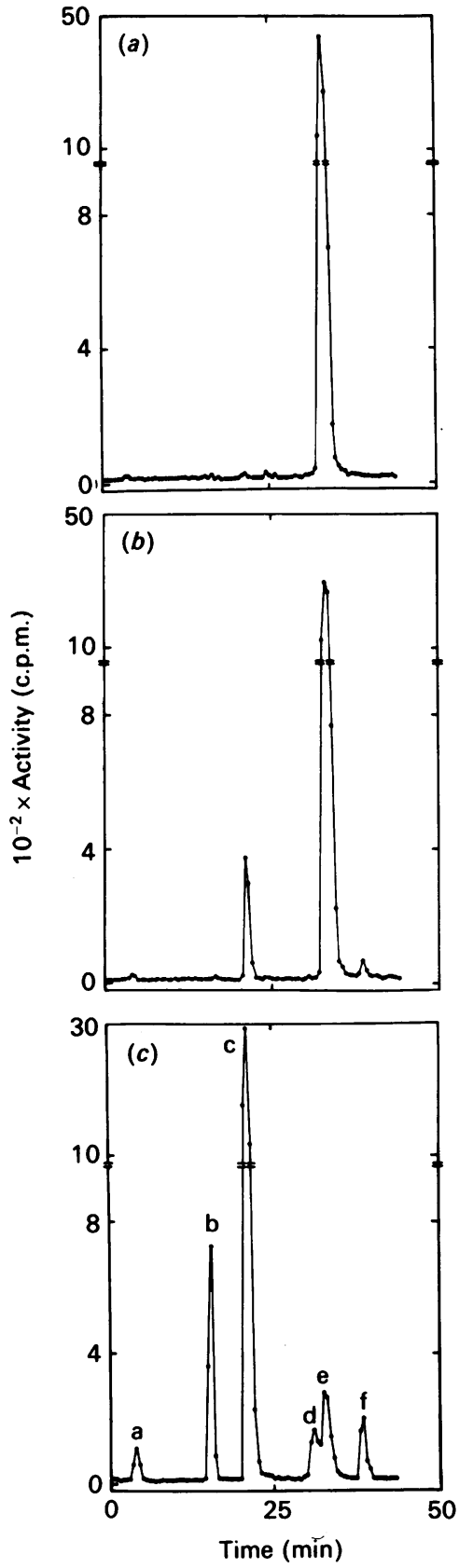

Fig. 2. Metabolism of $\left|{ }^{3} \mathrm{H}\right| \mathrm{D}-\operatorname{Ins}(1,4,5) P_{3}$ by permeabilized hepatocytes

Permeabilized hepatocytes were incubated at cell densities of $0.29 \mathrm{mg} / \mathrm{ml}(b)$ or $2.82 \mathrm{mg} / \mathrm{ml}(c)$. After $20 \mathrm{~min}$, either $\left[{ }^{3} \mathrm{H}\right] \mathrm{D}-\mathrm{Ins}(1,4,5) P_{3}$ (Amersham, $1 \mathrm{Ci} / \mathrm{mmol} ; 0.2 \mu \mathrm{Ci} / \mathrm{ml}$; final $\left.\left[\mathrm{D}-\operatorname{Ins}(1,4,5) P_{3}\right]=0.2 \mu \mathrm{M}\right)(b)$, or $\operatorname{DL}-\operatorname{Ins}(1,4,5) P_{3}$ $(10 \mu \mathrm{M})$ labelled with $\left[{ }^{3} \mathrm{H}\right] \mathrm{D}-\operatorname{Ins}(1,4,5) P_{3}(c)$ was added. Reactions were terminated after a further $5 \mathrm{~min}(b)$ or 30 min $(c)$. Peaks, identified by comparison with absorbance from added adenine nucleotides and by their coelution with authentic standards, were as follows: a, Ins; b, Ins $P_{1} ; \mathrm{c}, \operatorname{Ins}(1,4) P_{2} ; \mathrm{d}, \operatorname{Ins}(1,3,4) P_{3} ; \mathrm{e}, \operatorname{Ins}(1,4,5) P_{3}$; $\mathrm{f}, \operatorname{Ins}(1,3,4,5) P_{4}$. Incubation of $\left[{ }^{3} \mathrm{H}\right] \mathrm{D}-\operatorname{Ins}(1,4,5) P_{3}$ in the absence of cells $(a)$ caused no detectable degradation, while after a $5 \mathrm{~min}$ incubation with cells at low density $(b), 91 \%$ of the activity was recovered as $\left[{ }^{3} \mathrm{H}\right] \operatorname{Ins}(1,4,5) P_{3}, 8 \%$ as $\left[{ }^{3} \mathrm{H}\right] \operatorname{Ins}(1,4) P_{2}$ and $1 \%$ as $\left[{ }^{3} \mathrm{H}\right] \mathrm{Ins}(1,3,4,5) P_{4}$. These results establish that under the conditions used to determine the concentration-effect relationships shown in Fig. 1, there is no appreciable metabolism of $\operatorname{Ins}(1,4,5) P_{3}$. Cells incubated 
and $\operatorname{Ins}(1,4,5) P_{3}[\mathrm{~S}]_{3}$ therefore reflect their abilities to bind to and activate the receptor that regulates $\mathrm{Ca}^{2+}$ release from intracellular pools and are not a consequence of any difference in their relative rates of metabolism. We

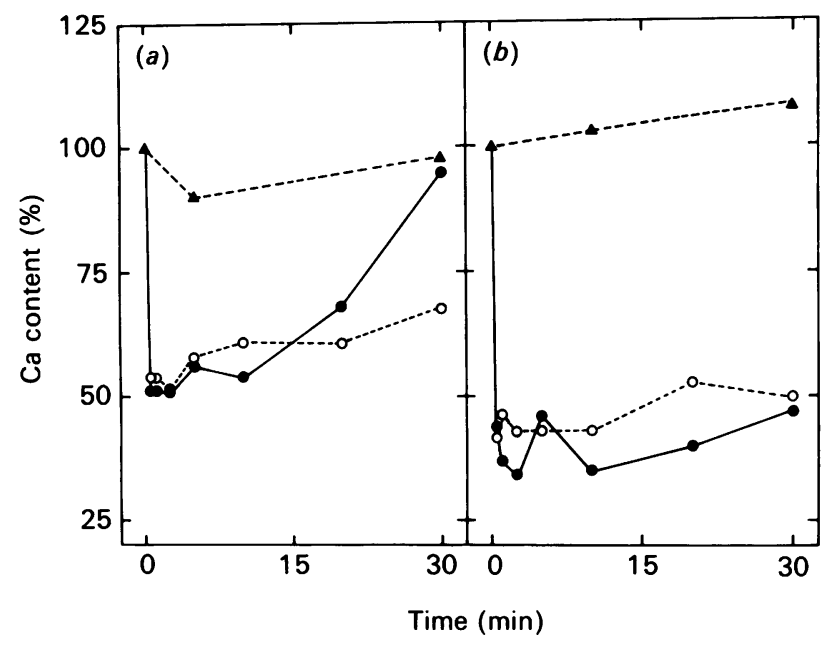

Fig. 3. Effects of 5-phosphatase on $\operatorname{DL}-\operatorname{Ins}(1,4,5) P_{3}$ and $\operatorname{DL}-\operatorname{Ins}(1,4,5) P_{3}|S|_{3}$

Permeabilized cells were labelled to steady state with ${ }^{45} \mathrm{Ca}$ and after $20 \mathrm{~min}\left(t=0\right.$ in Fig.) DL-Ins $(1,4,5) P_{3}(10 \mu \mathrm{M})$ or DL-Ins $(1,4,5) P_{3}[\mathrm{~S}]_{3}(10 \mu \mathrm{M})$ was added. Results are the means of duplicate determinations from a single experiment in which the cell densities were $2.82 \mathrm{mg}$ of protein $/ \mathrm{ml}$ (a) and $0.33 \mathrm{mg}$ of protein $/ \mathrm{ml}(b) . \Delta$, Control; $\bigcirc, \mathrm{DL}-$ $\operatorname{Ins}(1,4,5) P_{3} ; O$, DL-Ins $(1,4,5) P_{3}[\mathrm{~S}]_{3}$. Additional experiments provided similar results, a rapid release of $\mathrm{Ca}^{2+}$ after addition of DL-Ins $(1,4,5) P_{3}$ or DL-Ins $(1,4,5) P_{3}[\mathrm{~S}]_{3}$, and no subsequent re-accumulation of $\mathrm{Ca}^{2+}$ by cells incubated at low cell density $(0.31 \pm 0.11 \mathrm{mg}$ of protein $/ \mathrm{ml}, n=3$ ). However, when cells were incubated at high cell density $(1.88 \pm 0.47 \mathrm{mg}$ of protein $/ \mathrm{ml}, n=3)$, they re-accumulated $\mathrm{Ca}^{2+}$ after its release by DL-Ins( $\left.1,4,5\right)$ $P_{3}\left(52 \pm 9{ }_{0}, n=3\right.$ at $30 \mathrm{~s} ; 99 \pm 4 \%, n=3$ at $\left.30 \mathrm{~min}\right)$ but not after its release by DL-Ins $(1,4,5) P_{3}[\mathrm{~S}]_{3}(61 \pm 9 \%, n=3$ at $30 \mathrm{~s} ; 67 \pm 2 \%$ at $30 \mathrm{~min}$ ). conclude that $\operatorname{Ins}(1,4,5) P_{3}[S]_{3}$ is a full agonist for mobilization of intracellular. $\mathrm{Ca}^{2+}$ pools, and is only about 3-fold less potent than the naturally occurring messenger, D-Ins $(1,4,5) P_{3}$.

\section{Resistance of Ins $(1,4,5) P_{3}[S]_{3}$ to inactivation by dephosphorylation}

Degradation of D-Ins $(1,4,5) P_{3}$ by permeabilized hepatocytes has been shown to coincide with re-uptake of $\mathrm{Ca}^{2+}$ (Joseph et al., 1984). We therefore decided to examine the stability of DL-Ins $(1,4,5) P_{3}[\mathrm{~S}]_{3}$ by measuring $\mathrm{Ca}^{2+}$ re-uptake under conditions where $\mathrm{D}$-Ins $(1,4,5) P_{3}$ is degraded. Hepatocytes incubated at high cell density (about 10-fold more dense than in the experiments described above) rapidly degraded $\left[{ }^{3} \mathrm{H}\right] \mathrm{D}-\operatorname{Ins}(1,4,5) P_{3}$ (half-time about $10 \mathrm{~min}$ ) via the 5-phosphatase pathway with very little contribution from the 3-kinase pathway (Fig. $2 c)$. We compared the effects of DL-Ins $(1,4,5) P_{3}$ and DL-Ins $(1,4,5) P_{3}[\mathrm{~S}]_{3}$ under these conditions to see if the compounds differed in their susceptibility to inactivation by the 5-phosphatase. Almost maximal concentrations of each compound $(10 \mu \mathrm{M})$ released very similar amounts of $\mathrm{Ca}^{2+}$, but while the $\mathrm{Ca}^{2+}$ was soon re-sequestered after stimulation by $\operatorname{Ins}(1,4,5) P_{3}$, the $\mathrm{Ca}^{2+}$ pool remained empty for up to 30 min after stimulation by $\operatorname{Ins}(1,4,5) P_{3}$ $[\mathrm{S}]_{3}$ (Fig. 3a). Fig. 3(b) demonstrates that when the same experiment was repeated at low cell density - conditions under which there is minimal degradation of $\left[{ }^{3} \mathrm{H}\right] \mathrm{D}$ Ins $(1,4,5) P_{3}$ (Fig. $\left.2 b\right)$ - both compounds stimulated rapid release of $\mathrm{Ca}^{2+}$, and for both the $\mathrm{Ca}^{2+}$ pool remained empty for the duration of the experiment $(30 \mathrm{~min})$. These results establish that the receptor that mediates the actions of these compounds on intracellular $\mathrm{Ca}^{2+}$ pools does not desensitize during prolonged stimulation, an observation that supports earlier findings (Prentki et al., 1985). The prolonged actions of DL-Ins $(1,4,5) P_{3}[\mathrm{~S}]_{3}$ on the intracellular $\mathrm{Ca}^{2+}$ pools of cells incubated at high density must therefore result from its resistance to inactivation. Since under the conditions of these experiments 5-phosphatase-catalysed dephosphorylation is the major inactivation pathway, we conclude that

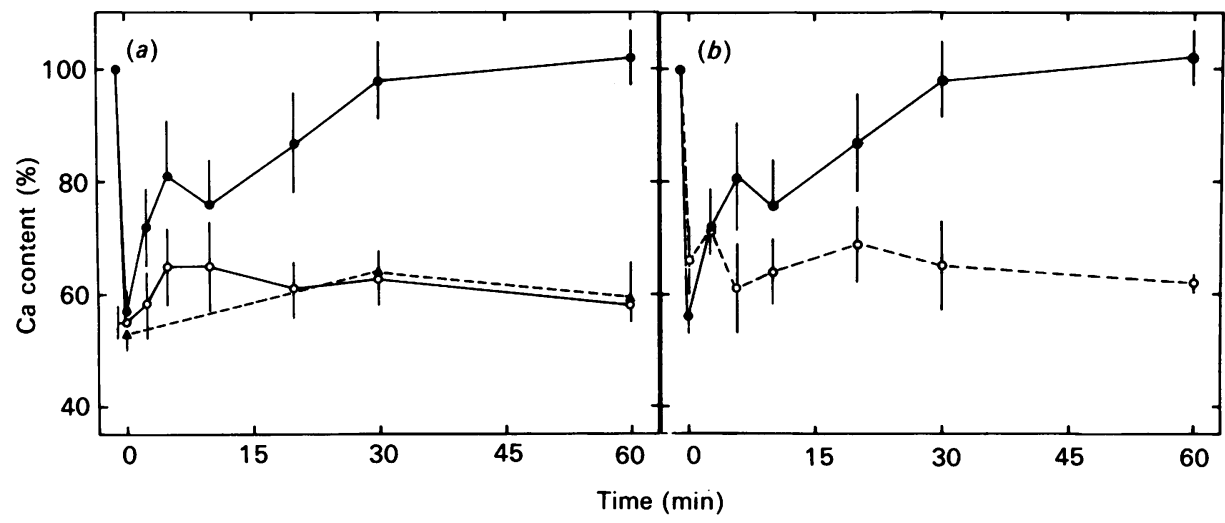

Fig. 4. Effects of 3-kinase on DL-Ins $(1,4,5) P_{3}$ and DL-Ins $\left.(1,4,5) P_{3} \mid S\right]_{3}$

DL-Ins $(1,4,5) P_{3}$ or DL-Ins $(1,4,5) P_{3}[\mathrm{~S}]_{3}$ were incubated with a rat brain supernatant under various conditions, and samples of the inositol phosphates removed at intervals for subsequent determination of their effects on the intracellular $\mathrm{Ca}^{2+}$ pools of permeabilized hepatocytes. Results, corrected for the small $\mathrm{Ca}^{2+}$ release stimulated by incubation medium alone, are shown as a percentage of ATP-dependent ${ }^{45} \mathrm{Ca}$ uptake (means \pm s.E.M. of duplicate determinations from at least four independent experiments). (a) Incubations of DL-Ins $(1,4,5) P_{3}$. $O$, Active kinase $+\mathrm{ATP} ; O$, active kinase, no ATP; $\Delta$, heat-inactivated kinase + ATP. (b) Incubations with active kinase and ATP. O, DL-Ins $(1,4,5) P_{3} ; \bigcirc$, DL-Ins $(1,4,5) P_{3}[\mathrm{~S}]_{3}$. 
DL-Ins $(1,4,5) P_{3}[\mathrm{~S}]_{3}$ is substantially resistant to hydrolysis by that enzyme.

\section{Resistance of Ins $(1,4,5) P_{3}[S]_{3}$ to inactivation by phosphorylation}

D-Ins $(1,3,4,5) P_{4}(5 \mu \mathrm{M})$, the product of phosphorylation of D-Ins $(1,4,5) P_{3}$ (Irvine et al., 1986), neither significantly stimulated $\mathrm{Ca}^{2+}$ release itself nor affected the release evoked by near-maximal concentrations $(10 \mu \mathrm{M})$ of either DL-Ins $(1,4,5) P_{3}$ or DL-Ins $(1,4,5) P_{3}[\mathrm{~S}]_{3}$ (results not shown). This result provides an opportunity to compare the sensitivity of DL-Ins $(1,4,5) P_{3}$ and the phosphorothioate analogue to phosphorylation which should coincide with loss of their abilities to release $\mathrm{Ca}^{2+}$ from intracellular pools. Treatment of DL-Ins $(1,4,5) P_{3}$ with a crude preparation of D-Ins $(1,4,5) P_{3} 3$-kinase in the presence of ATP completely inactivated its $\mathrm{Ca}^{2+}$-releasing activity within $30 \mathrm{~min}$ (half-time about $5 \mathrm{~min}$ ) (Fig. $4 a$ ). In parallel experiments, there was no loss of activity when ATP was omitted from the incubation or when the kinase preparation was first heat-inactivated, suggesting that the loss of activity of DL-Ins $(1,4,5) P_{3}$ is entirely attributable to its phosphorylation. H.p.l.c. analysis of parallel incubations that included DL-Ins $(1,4,5) P_{3}(100 \mu \mathrm{M})$ labelled with $\left[{ }^{3} \mathrm{H}\right] \mathrm{D}-\mathrm{Ins}(1,4,5) P_{3}(1.5 \mu \mathrm{Ci} / \mathrm{ml})$ demonstrated that by $30-60 \mathrm{~min}, 90 \%$ of the D-Ins $(1,4,5) P_{3}$ had been phosphorylated to Ins $(1,3,4,5) P_{4}$, with negligible formation of $\operatorname{Ins}(1,3,4) P_{3}$ and less than $3 \%$ metabolized to Ins, Ins $P_{1}$ and Ins $P_{2}$. These results demonstrate that under the conditions used for these incubations, the inactivation of $\operatorname{Ins}(1,4,5) P_{3}$ is entirely attributable to its phosphorylation to $\operatorname{Ins}(1,3,4,5) P_{4}$.

In complete contrast, even prolonged treatment $(60 \mathrm{~min})$ of DL-Ins $(1,4,5) P_{3}[\mathrm{~S}]_{3}$ with active kinase in the presence of ATP caused no loss of its ability to release $\mathrm{Ca}^{2+}$ (Fig. 4b). We conclude that while $\operatorname{Ins}(1,4,5) P_{3}$ is phosphorylated and thereby inactivated by a D-Ins$(1,4,5) P_{3}$ 3-kinase, $\operatorname{Ins}(1,4,5) P_{3}[\mathrm{~S}]_{3}$ is not a substrate for this inactivation pathway.

\section{Lack of effect of $\operatorname{Ins}(1,4,5) P_{3}[S]_{3}$ on phosphorylation of Ins $(1,4,5) P_{3}$}

The resistance of $\operatorname{Ins}(1,4,5) P_{3}[\mathrm{~S}]_{3}$ to phosphorylation prompted us to examine the possibility that it may nevertheless bind to the $\operatorname{Ins}(1,4,5) P_{3}$ 3-kinase and so inhibit phosphorylation of Ins $(1,4,5) P_{3}$. Under the conditions used to measure the activity of the 3-kinase, we have been unable to detect significant formation of Ins $(1,3,4) P_{3}$ : h.p.l.c. analysis revealed no such product, and incubations of $\operatorname{Ins}(1,4,5) P_{3}$ with the kinase in the absence of ATP failed to detect any $\operatorname{Ins}(1,4,5) P_{3} 5$ phosphatase activity. We therefore pursued the competition studies by incubating $\left[{ }^{3} \mathrm{H}\right] \mathrm{D}-\operatorname{Ins}(1,4,5) P_{3}$ with the crude kinase preparation, and separated the products by anion-exchange chromatography. Further justification for using anion-exchange chromatography rather than h.p.l.c. is provided by our finding that under conditions where $60-70 \%$ of a mixture of $\left[{ }^{3} \mathrm{H}\right] \operatorname{Ins}(1,4,5) P_{3}$ and Ins $\left(1,4,\left[{ }^{32} \mathrm{P}\right] 5\right) P_{3}$ was phosphorylated to Ins $P_{4}$, we found no change in the ratio of ${ }^{32} \mathrm{P} /{ }^{3} \mathrm{H}$ in the Ins $P_{3}$ fraction, indicating that there can have been no significant formation of $\operatorname{Ins}(1,3,4) P_{3}$.

During a prolonged incubation of $\left[{ }^{3} \mathrm{H}\right] \mathrm{D}-\operatorname{Ins}(1,4,5) P_{3}$ with the crude 3-kinase preparation, most of the $\operatorname{Ins}(1,4,5) P_{3}$ was phosphorylated to $\operatorname{Ins}(1,3,4,5) P_{4}$ as the concentration of substrate declined from $1 \mu \mathrm{M}$ to

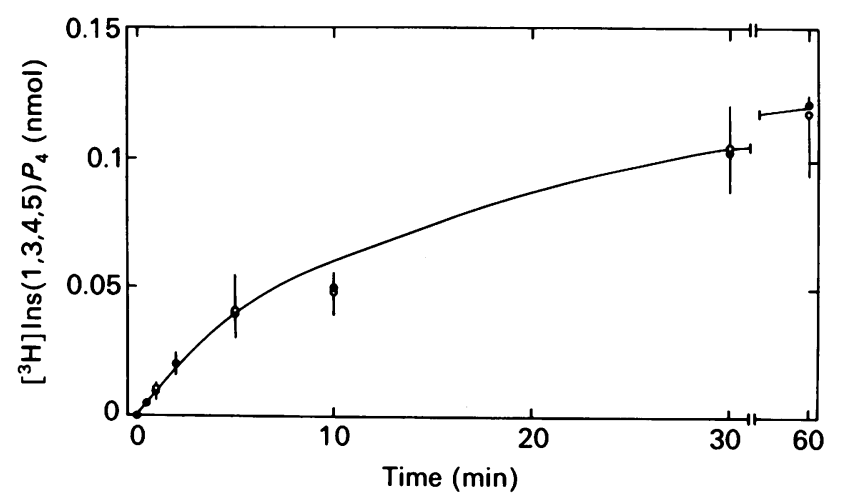

Fig. 5. Phosphorylation of $\left[{ }^{3} \mathrm{H} \mid \mathrm{D}-\operatorname{Ins}(1,4,5) P_{3}\right.$ in the presence and absence of DL-Ins $(1,4,5) P_{3}[S]_{3}$

$\left[{ }^{3} \mathrm{H}\right] \mathrm{D}-\mathrm{Ins}(1,4,5) P_{3}(1 \mu \mathrm{M})$ was incubated with the rat brain supernatant preparation in the presence of ATP. Samples of $200 \mu \mathrm{l}$ (containing $0.2 \mathrm{nmol}$ of $\operatorname{Ins}(1,4,5) P_{3}$ at the beginning of the incubation) were removed at intervals, and the products separated by anion-exchange chromatography. The rate of formation of $\left[{ }^{3} \mathrm{H}\right] \operatorname{Ins}(1,3,4,5) P_{4}$ was unaffected by the presence of DL-Ins $(1,4,5) P_{3}[\mathrm{~S}]_{3}(10 \mu \mathrm{M})$. Results are the means \pm S.E.M. of duplicate determinations from three independent experiments. $O,\left[{ }^{3} \mathrm{H}\right] \mathrm{D}-\operatorname{Ins}(1,4,5) P_{3}$ alone;,$\left[{ }^{3} \mathrm{H}\right] \mathrm{D}-\operatorname{Ins}(1,4,5) P_{3}+\mathrm{DL}-\operatorname{Ins}(1,4,5) P_{3}[\mathrm{~S}]_{3}$.

$0.38 \pm 0.1 \mu \mathrm{M}(n=6)$ (Fig. 5), well below the $K_{\mathrm{m}}$ of $0.6 \mu \mathrm{M}$ (Irvine et al., 1986). In parallel experiments, the rate of phosphorylation of $\left[{ }^{3} \mathrm{H}\right] \operatorname{Ins}(1,4,5) P_{3}$ to $\operatorname{Ins}(1,3,4,5) P_{4}$ was unaffected by the presence of a much higher concentration $(10 \mu \mathrm{M})$ of $\mathrm{DL}-\mathrm{Ins}(1,4,5) P_{3}[\mathrm{~S}]_{3}$ (Fig. 5). These results demonstrate that Ins $(1,4,5) P_{3}[\mathrm{~S}]_{3}$ does not compete with $\operatorname{Ins}(1,4,5) P_{3}$ for the $\operatorname{Ins}(1,4,5) P_{3}$ 3-kinase.

\section{DISCUSSION}

We have demonstrated that $\mathrm{D}-\operatorname{Ins}(1,4,5) P_{3}[\mathrm{~S}]_{3}$ is a potent analogue of the intracellular messenger D-Ins $(1,4,5) P_{3}$; it is a full agonist for mobilization of intracellular $\mathrm{Ca}^{2+}$ pools and only about 3 -fold less potent than the natural messenger. Similar results have been reported in other cell types including Xenopus oocytes and Swiss 3T3 cells (Taylor et al., 1988) and $\mathrm{GH}_{3}$ cells (Strupish et al., 1988). Consistent with these results is our recent finding that DL-Ins $(1,4,5) P_{3}$ and DL-Ins $(1,4,5) P_{3}$ $[\mathrm{S}]_{3}$ also differ by a factor of three in their affinities for a high affinity D-Ins $(1,4,5) P_{3}$-binding site in permeabilized hepatocytes (D. L. Nunn, B. V. L. Potter and C. W. Taylor, unpublished work). However, in cerebellar membranes a 6-fold difference in affinities has been reported (Willcocks et al., 1988), although it has not yet been possible to determine the effects of inositol phosphates on intracellular $\mathrm{Ca}^{2+}$ pools in this preparation.

Ins $(1,4,5) P_{3}$ is a substrate for both a 5-phosphatase enzyme and a 3-kinase enzyme, and metabolism by either route inactivates its ability to mobilize intracellular $\mathrm{Ca}^{2+}$ stores. However, our results suggest that $\operatorname{Ins}(1,4,5) P_{3}[\mathrm{~S}]_{3}$ is not a substrate for either of these pathways. Using another bioassay protocol, Willcocks et al. (1988) have confirmed the resistance of $\operatorname{Ins}(1,4,5) P_{3}[\mathrm{~S}]_{3}$ to inactivation by the 5-phosphatase. They showed that while treatment of $\operatorname{Ins}(1,4,5) P_{3}$ with human erythrocyte 5-phosphatase abolished its ability to displace $\left[{ }^{3} \mathrm{H}\right] \mathrm{D}-\operatorname{Ins}(1,4,5) P_{3}$ from specific binding sites in cerebellar membranes, the activity of $\operatorname{Ins}(1,4,5) P_{3}[\mathrm{~S}]_{3}$ was unaffected. 
Although not a substrate for the 5-phosphatase enzyme, DL-Ins $(1,4,5) P_{3}[\mathrm{~S}]_{3}$ is a potent inhibitor of the enzyme $\left(K_{\mathrm{i}}=6 \mu \mathrm{M}\right)$ (Cooke et al., 1988). However, at the concentration used in our experiments $(10 \mu \mathrm{M})$, Ins $(1,4,5) P_{3}[\mathrm{~S}]_{3}$ appears not to bind to the 3-kinase, since it is neither a substrate for the enzyme nor does it compete with the natural substrate.

While both the phosphorylation and dephosphorylation pathways inactivate the effects of the D-Ins $(1,4,5) P_{3}$ on intracellular $\mathrm{Ca}^{2+}$ pools, it has been suggested that at least one of the products, D-Ins $(1,3,4,5) P_{4}$, may itself be an intracellular messenger and regulate $\mathrm{Ca}^{2+}$ transport at the plasma membrane (Irvine \& Moor, 1986; Morris et al., 1987). The rapid turnover of D-Ins $(1,4,5) P_{3}$, and the possibility that it may be the source of other active intracellular messengers, have caused considerable experimental problems. Radioligand binding experiments and concentration-effect relationships, for example, may often be confused by metabolism of $\mathrm{D}$-Ins $(1,4,5) P_{3}$. Furthermore, the direct actions of D-Ins $(1,4,5) P_{3}$ have not been readily distinguishable from those that require its metabolism. One model that seeks to explain hormoneand D-Ins $(1,4,5) P_{3}$-stimulated oscillations in cytosolic $\left[\mathrm{Ca}^{2+}\right]$ suggests that it reflects oscillatory changes in the intracellular concentration of $\mathrm{D}-\operatorname{Ins}(1,4,5) P_{3}$, while another suggests that the oscillations result from oscillatory release of $\mathrm{Ca}^{2+}$ from an overloaded intracellular store that remains overloaded only as long as D$\operatorname{Ins}(1,4,5) P_{3}$ is able to keep the $\operatorname{Ins} P_{3}$-sensitive store empty (Berridge et al., 1988). We suggest that the activity of DLIns $(1,4,5) P_{3}\left[S_{3}\right]$ in a variety of cell types and its metabolic stability will make it the ligand of choice in studying the actions of the natural messenger. In addition, it may allow the proposed mechanisms underlying oscillations in cytosolic $\left[\mathrm{Ca}^{2+}\right]$ to be distinguished, and the relative roles of $\operatorname{Ins}(1,4,5) P_{3}$ and $\operatorname{Ins}(1,3,4,5) P_{4}$ in regulating $\mathrm{Ca}^{2+}$ entry at the plasma membrane to be determined.

This work was supported by grants from the Science and Engineering Research Council, the Erna and Victor Hasselblad Foundation and the Research Corporation Trust. B.V.L.P. is a Lister Institute Fellow. C.W.T. is a Royal Society Locke Research Fellow.

\section{REFERENCES}

Berridge, M. J. \& Irvine, R. F. (1984) Nature (London) 312 , 315-321
Berridge, M. J., Heslop, J. P., Irvine, R. F. \& Brown, K. D. (1984) Biochem. J. 222, 195-201

Berridge, M. J., Cobbold, P. H. \& Cuthbertson, K. S. R. (1988) Philos. Trans. R. Soc. London B, 320, 325-343

Burgess, G. M., McKinney, J. S., Fabiato, A., Leslie, B. A. \& Putney, J. W., Jr. (1983) J. Biol. Chem. 258, 15336-15345

Cooke, A. M., Gigg, R. \& Potter, B. V. L. (1987a) J. Chem. Soc. Chem. Commun. 1525-1526

Cooke, A. M., Gigg, R. \& Potter, B. V. L. (1987b) Tetrahedron Lett. 28, 2305-2308

Cooke, A. M., Nahorski, S. R. \& Potter, B. V. L. (1988) FEBS Lett. 242, 373-377

Downes, C. P. \& Michell, R. H. (1985) in Molecular Mechanisms of Transmembrane Signalling (Cohen, P. \& Houslay, M. D., eds.), pp. 3-56, Elsevier, Amsterdam

Eckstein, F. (1985) Annu. Rev. Biochem. 54, 367-402

Irvine, R. F. \& Moor, R. M. (1986) Biochem. J. 240, 917-920

Irvine, R. F., Letcher, A. J., Heslop, J. P. \& Berridge, M. J. (1986) Nature (London) 320, 631-634

Joseph, S. K., Thomas, A. P., Williams, R. J., Irvine, R. F. \& Williamson, J. R. (1984) J. Biol. Chem. 259, 3077-3081

Majerus, P. W., Connolly, T. M., Bansal, V. S., Inhorn, R. C., Ross, T. S. \& Lips, D. L. (1988) J. Biol. Chem. 263, 3051-3054

Morris, A. P., Gallacher, D. V., Irvine, R. F. \& Petersen, O. H. (1987) Nature (London) 330, 653-655

Parker, I. \& Miledi, R. (1986) Proc. R. Soc. London B 228, 307-315

Prentki, M., Corkey, B. E. \& Matschinsky, F. M. (1985) J. Biol. Chem. 260, 9185-9190

Sharpes, E. S. \& McCarl, R. L. (1982) Anal. Biochem. 124, $421-424$

Storey, D. J., Shears, S. B., Kirk, C. J. \& Michell, R. H. (1984) Nature (London) 312, 374-376

Strupish, J., Cooke, A. M., Potter, B. V. L., Gigg, R. \& Nahorski, S. R. (1988) Biochem. J. 253, 901-905

Taylor, C. W. \& Putney, J. W., Jr. (1985) Biochem. J. 232, 435-438

Taylor, C. W., Berridge, M. J., Brown, K. D., Cooke, A. M. \& Potter, B. V. L. (1988) Biochem. Biophys. Res. Commun. 150, 626-632

Tennes, K. A., McKinney, J. S. \& Putney, J. W., Jr. (1987) Biochem. J. 242, 797-802

Willcocks, A. L., Cooke, A. M., Potter, B. V. L. \& Nahorski, S. R. (1987) Biochem. Biophys. Res. Commun 146, 1071-1078

Woods, N. M., Cuthbertson, K. S. R. \& Cobbold, P. H. (1986) Nature (London) 319, 600-602

Wreggett, K. A. \& Irvine, R. F. (1987) Biochem. J. 245, 655660

Received 27 October 1988; accepted 29 December 1988 